Marta NiEWIEczerzal

Uniwersytet Warszawski

Muzeum Książki Dziecięcej

\title{
Stare I NOWE MiaSto. PRZySZlość boHateróW WARSZAWSKICH LEGEND
}

Baśnie i legendy związane są z czasem przeszłym. Już sam język wskazuje, że opowieści snute są o dawnych dziejach, formuły typu: „dawno, dawno temu”, „zdarzyło się kiedyś..." odnoszą się do czasu przeszłego. Narrator opowiada historię, która wydarzyła się przed wiekami i usłyszał ją od kogoś innego lub sam uczestniczył w niej dawno temu, a teraz dopiero opowiada ją słuchaczom. Wciąż żywe pozostaje jednak pierwotne pragnienie opowiadania historii, być może dlatego tradycyjne wersje baśni i legend powracają w zmienionej formie, tak, by dostosować się do nowych czasów. Niewątpliwie zmieniający się świat, pewne przemiany społeczne i kulturowe mają ogromny wpływ na wszelkiego typu opowieści oraz na samo na postrzeganie legend i postaci z nimi związanych. Eksperymentowanie z baśniami, legendami czy podaniami to nie rzecz nowa i można ją zaobserwować na przestrzeni wieków. Baśń odpowiada na pragnienia i potrzeby ludzkie $\mathrm{w}$ danym czasie, zatem potrzeba dostosowania jej do aktualnego okresu dziejów wciąż pozostaje żywa, ale $\mathrm{z}$ jednoczesnym zakwestionowaniem pewnego określonego jej modelu. Pierwowzór staje się szczególnie plastycznym tworzywem, rekwizytornią do dalszych reinterpretacji (Kostecka 2014). Problemem pozostaje występowanie równolegle utworów zbliżonych do siebie gatunkowo, tj. baśń, podanie, legenda, na co słusznie zwracają uwagę badacze (m.in. Jolanta Ługowska, Ryszard Waksmund, Gertruda Skotnicka). Skotnicka pisze: „Podania $\mathrm{i}$ legendy są $\mathrm{W}$ rozmaity sposób związane $\mathrm{z}$ mitami, na przykład podania o najdawniejszej polskiej przeszłości wywodzą się z mitu prapoczątku, mitu genezy, kształtującego wyobrażenia o powstaniu i porządku wszechświata" (Skotnicka 2008: 171). Jack Zipes również wspominał o wspólnych początkach pewnych mitów i opowieści ludowych, których we współczesnych narracjach ustnych i literackich nie sposób rozdzielić (Zipes 1993: 3). Jak zauważa Antoni Porczak: „,...] cała nasza rzeczywistość staje się hybrydowa i niejednorodna gatunkowo" (Leszczyński 2006: 157). Celem niniejszego artykułu jest przedstawienie wybranych postaci z tradycyjnych legend (których akcja dzieje się w przestrzeni miejskiej) oraz ich postmodernistycznych wersji. Rozważę, jak zmienia się podejście do utrwalonych w kulturze potworów oraz innych postaci pochodzących z legend, jaka czeka je przyszłość? Czy one również dorastają i dojrzewają wraz $\mathrm{z}$ upływającym czasem? Z bogatego zbioru legend jako charakterystyczne przykłady wybrane zostały przede wszystkim legendy warszawskie i postaci z nimi związane m.in: Złota Kaczka czy Bazyliszek. Podstawą materiałową była wydana w 2016 roku antologia Legend warszawskich w wyborze Anny Marty Zdanowskiej, zawierająca wersje wielu legend oraz powieści Marcina Szczygielskiego Klatwa dziewiatych urodzin oraz tomu Legendy polskie. Allegro opublikowanego w formie e-booka w 2015 roku.

To, co proponują nam autorzy omawianych tekstów, wpisuje się w obecny trend intertekstualnych gier $\mathrm{z}$ tradycją. Według Weroniki Kosteckiej ,gra z tradycja z powszechnie znanymi baśniowymi motywami, schematami fabularnymi czy morałami - stanowi naczelną zasadę rządzącą baśnią postmodernistyczną" (Kostecka 2014: 197). Jak pisze badaczka, baśń postmodernistyczna, „posługując się różnorodnymi intertekstualnymi strategiami, ożywia tradycję, która w »literaturze wyczerpania« staje się zbiorem przewidywalnych, gotowych rozwiązań. Wskazuje, że jedynie twórcze przetwarzanie kultury - nie zaś tylko jej odtwarzanie - oraz ciągły dialog z »pre- 
tekstem « stanowią szansę na przezwyciężenie postmodernistycznego kryzysu" (Kostecka 2014: 161).

Wykorzystywanie przez autorów bezpośrednich nawiązań do postaci i motywów $\mathrm{z}$ legend również można potraktować jako postmodernistyczną grę z tradycją.

Poddana analizie Klątwa dziewiątych urodzin Marcina Szczygielskiego należy do cyklu o przygodach nastoletniej Mai. Wart uwagi pozostaje sposób, w jak autor wykorzystał legendy warszawskie, służące mu jako swoiste tworzywo, wokół którego osnuł swoją opowieść. Jego zamysł trafnie odzwierciedlają słowa pojawiające się na kartach powieści: „Z legendami jest tak, że każdemu wydają się doskonale znane, ale gdy przychodzi do szczegółów, niewiele osób ma o nich pojęcie" (Szczygielski 2016: 98). Legendy funkcjonują w pamięci zbiorowej jako pewien znany większości punkt odniesienia, dzięki temu łatwo można poddać je pewnym przekształceniom, niejako napisać historię na nowo, która jednak wciąż będzie wydawała się znajoma.

W powieści Szczygielskiego Maja, w związku z ciążącą nad nią klątwą, musi odnaleźć cegłę pochodzącą ze Szczecina, która po wojnie znalazła się w odbudowanej Warszawie. Podczas poszukiwań spotyka się z postaciami należącymi do kanonu legend warszawskich. Jak sam autor w jednym z wywiadów mówi:

Mam wrażenie, że choć Warszawa jest miastem o długiej, skomplikowanej, burzliwej historii, to jednak legendy z nią związane prawie odeszły już w niepamięć. $Z$ wielu mitów, które rodziły się na przestrzeni setek lat dziejów naszej stolicy, do dziś przetrwało zaledwie kilka, na dodatek w mocno okrojonej formie. Nie wiem nawet, czy można określić je mianem „świętości”, bo warszawska Syrenka, Złota Kaczka, Wars i Sawa funkcjonują teraz raczej jako stołeczne gadżety, a nie cenne pamiątki kultury i historii miasta. W Klatwie dziewiatych urodzin pojawiają się więc jako sfrustrowane, zapomniane postacie, które z mniejszym lub większym powodzeniem próbuja znaleźć dla siebie miejsce we współczesnej stolicy - ale jednak są wciąż żywe (Szczygielski w rozmowie z Ewą Świerżewską 2016 ${ }^{1}$ ).

Ożywianie na nowo zapomnianych postaci oraz ukazanie, że ich potencjał nie został jeszcze wyczerpany, wpisują się we wspomniane już postmodernistyczne strategie. Znani odbiorcy bohaterowie dojrzewają i przystosowują się do warunków otoczenia - w tym wypadku do przestrzeni miejskiej. Warto w tym miejscu pokrótce przyjrzeć się samemu miastu, które zajmuje ważne miejsce w literaturze w ogóle. Co ciekawe, w literaturze dla dzieci, jak pisze Violetta Wróblewska:

[...] przestrzeń realnie istniejącego miasta bywa zazwyczaj mało eksponowanym elementem świata przedstawionego. Pełni funkcję tła zdarzeń, dookreśla pod względem charakterologicznym bohaterów, niekiedy wpływa na przebieg działań protagonisty. Jako że miasto, podlegając daleko idącej funkcjonalizacji, odgrywa przede wszystkim rolę usługową wobec innych części ukazanej rzeczywistości, rzadko kiedy staje się składnikiem literackim w pełni samodzielnym bądź równoważnym protagonistom (Wróblewska 2016: 79)

Podobnie dzieje się w omawianych tekstach, jednak w powieści Szczygielskiego możemy zauważyć pewną prawidłowość: tak, jak miasto żyje, zmienia się, tak samo i związane $\mathrm{z}$ nim legendy muszą ewoluować, ponieważ są jego częścią, pewną niematerialną tkanką. W takim rozumieniu miasto pełni funkcję nieokreślonej siły sprawczej, bodźca do nieuchronnych zmian.

${ }^{1}$ Wywiad: Od mitów do celebrytów - rozmowa z Marcinem Szczygielskim https://www.empik.com/przecinek-i-kropka/od-mitow-do-celebrytow-rozmowa-zmarcinem-szczygielskim, 16515,a) [5.01.2019]. 
Pierwszą napotkaną przez główną bohaterkę postacią z legend jest Złota Kaczka, w zależności od wariantu, była to albo ,zła boginka”, która wraz z diabłem namawia do egoizmu i chciwości, albo księżniczka, której nikt nie potrafi pomóc i uratować (Zdanowska 2016). Zadaniem dzielnego śmiałka jest wydanie dużej sumy pieniędzy na zbytki w bardzo krótkim czasie, czego nikt nie potrafi uczynić. Natomiast w powieści Szczygielskiego Złotą Kaczką okazuje się być Złoty Kaczor. Mieszka, tak jak w tradycyjnej wersji, na Powiślu, pod Zamkiem Ostrogoskich. Co ważne, przestrzeń miejska również się zmienia i teraz $\mathrm{w}$ tym zamku mieści się Muzeum Chopina, a znakiem pamięci o legendzie jest jedynie stojący pomnik złotej kaczki. Jak się przekonują bohaterki powieści po przekręceniu złotej figury ptaka na postumencie, trafiają się do ukrytych podziemi i odnajdują to, czego (a raczej kogo) szukały. Czytamy: „Blask bił od złocistej wody wypełniającej owalny basen wpuszczony w podłogę. Pośrodku sadzawki kołysała się na falach Złota Kaczka. Na łebku miała lekko przekrzywioną koronę. Czytała gazetę" (Szczygielski 2016 : 128). Początkowo opis brzmi, jak ten z klasycznej legendy, dopiero trzymana przez kaczkę gazeta rozbija utrwalone wyobrażenie legendy. Jak się też przekonuje za chwilę czytelnik, tak naprawdę jest to Złoty Kaczor, który w dodatku twierdzi, że padł ofiarą cwanego szewczyka nieroba i przez niego ma zszarganą reputację na kilka stuleci. Neguje on historię, którą Maja przeczytała o nim w internecie. W wersji Oppmana Złota Kaczka jest oceniana negatywnie - „Bo zła to musiała być boginka, kiedy za warunek stawiała: sobie, nie komu!". Natomiast Złoty Kaczor twierdzi, że jego historia jest przekłamana - Szewczyk to wszystko wymyślił, a prawda jest zupełnie inna. Mamy tutaj do czynienia z postmodernistycznym zabiegiem ujawniania „prawdziwej historii”. Przed czytelnikiem odsłania się niesfałszowany życiorys Kaczora, który sam jest narratorem tej opowieści. To Kaczor, a nie Szewczyk, jest pokrzywdzony w tej legendzie: „Ten złośliwy leń wszystkim rozpowiedział, że wcale nie jestem kaczorem, tylko kaczką [...]. I to w dodatku podłą, wredną, nieużytą kaczką, która zabroniła mu podzielić się bogactwami z innymi!" (Szczygielski 2016: 134). Tym samym zostaje odwrócona hierarchia postaci względem tradycyjnej wersji. Przed czytelnikiem odsłania się prawdziwy przebieg wydarzeń i jednocześnie przywrócone zostaje dobre imię postaci tradycyjnie uważanej za antagonistę (Kostecka 2014: 133).

Kolejną legendarną postacią z nowym życiorysem w powieści Szczygielskiego jest Syrenka Warszawska, która według Złotego Kaczora „ostatnio nieco wyszła z formy i trochę się roztyła, ale na pewno trzyma płetwę na pulsie miasta" (Szczygielski 2016: 138). Po pewnych problemach ze znalezieniem domu Syreny, bohaterki odnajdują wejście do tunelu, z którego dobiega ich szczególna melodia rozpoznana jako melodia Ariel, czyli Małej Syrenki, znanej odbiorcy z realizacji filmowej Disneya (1989), stająca sie jednocześnie pewnym symbolem przemian i wyobrażeń na temat legend. W tekście Szczygielskiego to nawiązanie pokazujące $\mathrm{z}$ czym kojarzy się syrenka, ma zabarwienie ironiczne, ponieważ, jak czytamy dalej:

$\mathrm{Na}$ kanapie leżała okropnie gruba kobieta w średnim wieku, ubrana w poplamiony biały T-shirt z napisem „I love Warsaw”. Gęste ciemne włosy, przetkane pasmami siwizny, upięła w nieporządny kok. Zamiast nóg miała rybi ogon ozdobiony kolorowymi kapslami od butelek. Jadła kopytka ze skwarkami i oglądała „Małą Syrenkę” na turystycznym czarno-białym telewizorku, do którego podłączony był przedpotopowy magnetowid (Szczygielski 2016: 171).

To już nie wyobrażenie $\mathrm{z}$ tradycyjnej legendy, czyli piękna syrena $\mathrm{z}$ anielskim głosem, tylko zaniedbana kobieta $\mathrm{z}$ ogonem, która nie wymawia głoski $r$, co staje się dodatkowym elementem komicznym. Przytyła, ponieważ podkrada jedzenie przywożone do stolicy w słoikach (m.in. przez osoby pracujące i studiujące): „Od 
pewnego czasu do Wałszawy przysyłane są z całego kłaju tony słoików z takim pysznym jedzeniem" (Szczygielski 2016: 174) - aluzja do nazywania przez mieszkańców Warszawy osób przyjezdnych, szczególnie studentów, „słoikami”. Syrenka Warszawska nie jest już małą syrenką, lecz dojrzałą kobietą z siwymi włosami, która ma zaburzenia metabolizmu i przybrała na wadze (Szczygielski 2016: 174). Postać ta oprócz fizycznych różnic związanych ze starzeniem się, doświadcza również zmian zależnych od miasta, które tak samo podlega wielorakim transformacjom i rozwija się wraz z czasem. To między innymi powojenna odbudowa Warszawy miała wpływ na relację Katarzyny z ukochanym. Viadrus, bóg rzeki Odry, obraził się na nią, ponieważ wszystkie cegły wysyłane były do stolicy zamiast posłużyć do naprawy Szczecina. W powieści jest również mowa o budowie metra, które Katarzyna chciała podtopić (sam fakt zalania stacji metra podczas jej budowy jest zgodny z prawdą). Historia syrenki jest więc wpleciona w historię Warszawy w każdym momencie dziejowym miasta.

Kolejne legendarne postaci w powieści Szczygielskiego to Wars i Sawa, które również dojrzały i zmieniły się we współczesnej Warszawie. Maja odnajduje je w galerii na Marszałkowskiej, która nazywa się Wars i Sawa i znana jest wszystkim warszawiakom. Sawa „ubrana była w elegancką łososiową garsonkę, na nogach miała wysokie beżowe szpilki, a z jej ramienia zwisała na złotym łańcuchu nieduża czarna torebka ze złotym emblematem" (Szczygielski 2016: 212). Natomiast Wars przechadzał się W popielatomorskim garniturze, „starannie uczesany, jego ciemne włosy połyskiwały od żelu" (Szczygielski 2016: 212). Relacja obu postaci jest czuła i swobodna, zwracają się do siebie „Warsiu” „Sawuńciu” - jak stare dobre małżeństwo. Nie zajmowali się łowieniem ryb, jak mówi stary przekaz, ale „przestawili się na łowienie okazji" (Szczygielski 2016: 214). Są dobrze prosperującymi handlowcami. Kierują oni Maję do nadwiślańskiej Biedy zamieszkującej wołowy gnat, gdyż tylko ona zna odpowiedź, gdzie znajduje się poszukiwana przez Maję cegła. Jednak Biedy nie można wypuścić, (by powiedziała, co wie), ponieważ cały kraj według Warsa i Sawy popadłby w nędzę. Odnajdujemy tutaj odwołanie do legendy o dwóch braciach, biednym i bogatym, którzy żyli w Warszawie. Walerek Orzeszek, biedniejszy z braci, uwięził prześladującą go Biedę w gnacie, by wreszcie zaczęło mu się powodzić. W toku akcji powieści wkrótce okazuje się, że Wars i Sawa to sprytni kapitaliści, którzy uknuli intrygę, a Bieda pomaga im na swój sposób - zakopana pod domem towarowym psuje interesy konkurencji.

Przykłady te pokazują, że wszystkie omówione legendarne postaci żyją razem z miastem, z nim dorastają i zmieniają się. Dodatkowo można dostrzec wprowadzanie rozbudowanej psychologii bohaterów, co Kamila Kowalczyk podaje jako jeden z podstawowych mechanizmów we współczesnych renarracjach (Kowalczyk 2016: 7). Badaczka wyróżnia je w kontekście przekształceń baśni braci Grimm. Sądzę jednak, że mechanizmy te można odnieść również do innych tekstów pierwotnie pochodzących z kultury oralnej. Bohaterowie zyskują nowy życiorys, dowiadujemy się nowych faktów $\mathrm{z}$ ich życia, nie są już tak bardzo schematyczni jak w pierwowzorach. Można zadać sobie pytanie, jaka czeka je przyszłość? Szczygielski wykorzystuje w swojej powieści pewne utrwalone w świadomości zbiorowej obrazy postaci ze słynnych opowieści i rozbija legendę o ich życiu oraz dopisuje dalsze ciągi. Wars i Sawa funkcjonujący do tej pory jako pozytywni bohaterowie stają się antagonistami. Złota Kaczka również odgrywa nowe role i zmianie ulega jej płeć w porównaniu do dawnego przekazu. Zastosowane przez autora mechanizmy powodują, że historia legendarnych bohaterów uzupełniona jest o nowe wątki dotyczące zarówno czasów przeszłych, jak 
i ówczesnych, w których teraz funkcjonują. Interesujące wydaje się także budowanie historii „co było potem”, co działo się z tymi postaciami po zakończeniu, czy dalej żyją, co teraz robią? Jak im się powodzi? Wpisuje się to w tradycję kontynuowania historii nie tylko przez fanów, czytelników (m.in. fanfic), lecz także przez samych autorów. Powieść Szczygielskiego uświadamia również, że legendy funkcjonują nie tylko jako zapomniana tradycja, lecz także jako żywa opowieść inspirująca do dalszych interpretacji. Strategia sequela i prequela jest również jednym ze sposobów modyfikowania historii wyjściowej (Kowalczyk 2016). Sequel przedstawiający późniejsze losy bohatera w przypadku omówionych postaci - „wyznacza specyficzny rodzaj uzupełnienia i konkretyzacji” (Kowalczyk 2016: 7) fabuł legendarnych.

Podobne podejście do legend jako swoistego tworzywa mają twórcy Legend polskich tworzonych pod patronatem Allegro. Analizowany e-book towarzyszył filmom wyświetlanym na stronie internetowej youtube.com, gdzie cieszyły się one ogromną popularnością ${ }^{2}$. Jedną z opowieści, której akcja toczy się w Warszawie, jest Spójrz mi w oczy Elżbiety Cherezińskiej, inspirowana legendą o Bazyliszku. Istnieje wiele tradycyjnych warantów tego podania, jednak niezmiennie pojawia się ulica Krzywe Koło, znajdująca się na Starym Mieście w Warszawie. Legendy warszawskie. Antologia (2016) prezentują nam aż sześć wersji tej legendy, ich autorzy to między innymi Edmund Jezierski, Artur Oppman, Wanda Chotomska (Zdanowska 2016). Bazyliszek znany nam z dawnych przekazów to przeraźliwy stwór zamieszkujący staromiejskie piwnice i zabijający wzrokiem każdego, kto się zbliży. Oczywiście w każdej z wersji występują pewne różnice dotyczące potwora, jednak nie są one tak znaczące. Dotyczą one m.in. wyglądu Bazyliszka, zależnie od wariantu czytamy: „niby kogut, niby wąż” (Oppman 2016: 71), „miał skrzydła jak nietoperz, ogon jak krokodyl, łapy zakończone szponami” (Chotomska 2016: 96), „wyglądał trochę jak dinozaur, trochę jak smok” (Gal 2016: 109). Natomiast wizerunek, który pojawia się w tekście Elżbiety Cherezińskiej Spójrz mi w oczy, jest szczególną interpretacją legendarnego potwora. Mamy tu do czynienia z futurystyczną wizją tej legendy. Akcja dzieje się w odległej przyszłości, co można wywnioskować na podstawie prezentowanej technologii. Interesującym zabiegiem jest przedstawienie Polski, która wróciła do systemu monarchicznego - na tronie zasiada Anna Jagiellonka XIII, a wokół niej tłoczy się szlachta w tradycyjnych sarmackich strojach (Rak i in. 2015). Niekonkretna przyszłość została ubrana w tradycyjny kostium - państwo nazwa się Królestwo Polskie, pojawiają się również elementy związane ze znaną odbiorcy historią $(\mathrm{m}$. in. nazwiska i imiona królów oraz królowych oraz stroje sarmackie). Poddani z niecierpliwością oczekują ogłoszenia decyzji monarchini $\mathrm{w}$ sprawie wyboru jej przyszłego małżonka i ojca następcy tronu. Prasa spekuluje na kogo padnie wybór, jednak spokój na dworze królowej zakłóca niedawne, nadal niewytłumaczone zaginięcie piętnastu uczniów elitarnej Szkoły Paziów. Jeden z gości na dworze polskiej królowej to chiński uczony, pan Li, kryjący zaskakującą tajemnicę, a już pewną wskazówką może być wynajęcie przez niego apartamentu na ulicy Krzywe Koło. Jak się okazuje w toku akcji, to on jest Bazyliszkiem chcącym podstępnie wykorzystać i zapłodnić królową, zdecydowaną na przywrócenie starej dynastii za pomocą metody pana Li, która pozwala pobrać materiał genetyczny od jednego z dawnych królów Polski i na bazie wyabstrahowanego z nich DNA, wyhodować żywy plemnik. Niezmiennym znakiem Bazyliszka w dawnych

2 Świadectwem tego jest między innymi bardzo duża liczba wyświetleń filmów na portalu youtube.com. Przykładowo film o Panu Twardowskim pt. TWARDOWSKY ma ponad $5 \mathrm{mln}$ wyświetleń (stan na styczeń 2019 roku). 
przekazach był zabójczy wzrok, a w wersji Cherezińskiej Pan Li nosi soczewki, pod którymi ukrywa tę szczególną cechę. Sposób, w jaki potraktowała autorka postać Bazyliszka, dobrze oddaje dialog, który toczy się między Panem Li a dwoma chłopcami:

Pan Li - żachnął się Paweł. - Co za banalny kryptonim bazyliszka! Jak wszyscy daliśmy się nabrać!

- Jest pan wybrykiem natury - zadziwiająco spokojnie powiedział Piotr.

- Potworem poczętym wbrew niej - dodał bliźniak. - Jak w legendzie, wyklutym pewnie z koguciego jaja!

- Oj, oj, jacy zasadniczy! - zaśmiał się Li. - Czy widzicie ogon, koguci łeb i tę całą resztę? Można to ująć inaczej, bardziej współcześnie, mówiąc, że jestem...

- Supermenem? - roześmiał mu się w twarz Paweł. -

Jest pan wybrykiem natury i wynaturza pan wszystko, czego się tknie.

- Przeciwnie. Moją domeną jest doskonałość. Pigmalion chciał wyrzeźbić idealny kamień i tchnąć w niego życie, ja biorę życie i zamieniam w idealny kamień. To nie podlega dyskusji (Rak i in. 2015).

Jak podaje Kowalczyk: ,poprzez renarracje rozumiane są takie teksty kultury, które bazują przede wszystkim na zakorzenionym w masowej wyobraźni (treściowym i gatunkowym) wzorcu (...) (Kowalczyk 2016: 6). Istniejący utrwalony obraz Bazyliszka ulega transformacji. Cała intryga Pana Li/Bazyliszka polegała na opanowaniu Starej Europy, nie tylko Polski. Czarny charakter, potwór z legend otrzymuje tutaj całkiem nową, swoją historię, staje się głównym bohaterem tej futurystycznej wersji. Wykorzystany plastyczny tradycyjny kostium funkcjonuje w całkowicie innych realiach.

Wybrane przeze mnie przykłady prezentują dwa modele skonfrontowania legendy z szeroko rozumianą przyszłością. W omawianych utworach odnajdujemy proponowane przez Kamilę Kowalczyk (2016: 7) mechanizmy modyfikowania wyjściowej historii (m.in. osadzenie baśniowej fabuły w nowej konwencji, nowe elementy fabularne, psychologizacja baśniowych postaci, odwrócenie hierarchii postaci). Obraz zarówno starego, jak i nowego miasta zbudowany jest z elementów rzeczywistych i fantastycznych, które jednocześnie obok siebie funkcjonują, tworząc tym samym legendarne uniwersum. Czas wpływa na topografię, architekturę, społeczeństwo, jednak najważniejsze punkty wokół, których koncentruje się tożsamość miasta, pozostają niezmienne. Legendy pozostają spoiwem łączącym stare i nowe miasto. Szczygielski wybiera postaci z kanonu legend warszawskich i dopisuje im dalszą historię. Przez nadanie im konkretnych życiorysów i zaznaczenie ich bytności na współczesnej mapie Warszawy autor pokazuje, że nie są one zastałym tworem i reliktem przeszłości. Ponieważ jednym z budulców miasta są legendy, one również wpływają na tożsamość miasta i jego mieszkańców. Natomiast Legendy polskie Allegro pokazują, jak można tradycyjny przekaz ubrać w nowy futurystyczny kostium. Twórcy osadzają legendarną fabułę w całkiem nowej konwencji gatunkowej i tworzą historię wzbogacona o nowe elementy fabularne. Stwory zamieszkujące miasto zarówno w przeszłości, jak i w teraźniejszości oraz wyobrażonej przyszłości są jednym z ważniejszych elementów pojawiających się w omawianych tekstach. Wraz z upływem czasu dorastają i zmieniają się wraz z samym miastem, co szczególnie widoczne jest podczas zestawienia tradycyjnych przekazów $\mathrm{z}$ ich postmodernistycznymi transformacjami. Niekiedy antagoniści otrzymują całkiem nową historię i stają się głównymi bohaterami wariantywnych opowieści, odwrócona zostaje również hierarchizacja postaci. Dopiero dzięki istnieniu w masowej pamięci pewnego obrazu 
potwora (np. bazyliszka czy złotej kaczki) możliwe są późniejsze jego przekształcenia. Intertekstualne zabiegi budowania opowieści prawdziwej, negowanie tradycyjnej wersji jednocześnie budują kolejną opowieść, wokół której być może powstaną kolejne. Przedstawione teksty i mechanizmy w nich obecne pokazują, że wspólną cechą postmodernistycznych opowieści jest gra $\mathrm{z}$ tradycją literacką, która powoduje, że wiele baśni, legend, podań może wciąż żyć i ewoluować wśród odbiorców współczesnej kultury.

\section{Bibliografia}

KOSTECKA, W. (2014). Baśń postmodernistyczna: przeobrażenia gatunku. Warszawa: SBP.

KOWALCZYK, K. (2016). Baśń w zwierciadle popkultury. Renarracje baśni zbioru Kinder- und Hausmärchen Wilhelma $i$ Jakuba Grimmów $w$ przestrzeni kultury popularnej. Wrocław: Polskie Towarzystwo Ludoznawcze.

ŁUGOWSKA, J. (1993). W świecie ludowych opowiadań. Wrocław: Wydawnictwo Uniwersytetu Warszawskiego.

PorCZAK, A. (2006). Od pigmentu do piksela. Kraina ułudy. W: G. Leszczyński (red.). Kulturowe konteksty baśni, t. 2. Poznań: Centrum Sztuki Dziecka.

RAK, R., Wegner, R. M., Cherezińska, E., KosiK, R., MAŁecki, J., Orbitowski, Ł. (2015). Legendy polskie. Warszawa: Powergraph Sp. Z o.o. Pozyskano z https://allegro.pl/legendy\#ebook.

SKOTNICKA, G. (2008). Barwy przyszłości. O powieściach historycznych dla dzieci i młodzieży 1939-1989. Gdańsk: słowo/obraz terytoria.

SZCZYGIELSKI, M. (2016). Klątwa dziewiatych urodzin. Warszawa: Wydawnictwo Bajka.

WróBlEWSKA, V. (2014) Od potworów do znaków pustych. Ludowe demony w polskiej literaturze dla dzieci. Torun: Wydawnictwo Naukowe Uniwersytetu Mikołaja Kopernika.

WRÓBLEWSKA, V. (2016). Od przestrzeni realnej do wyimaginowanej - Toruń w literaturze dla dzieci. W: W. Kostecka, M. Skowera (red.), Geografia krain zmyślonych. Wokół kategorii miejsca i przestrzeni w literaturze dziecięcej, młodzieżowej fantastycznej. Warszawa: SBP.

ZDANOWsKA, A. M. (2016). Legendy warszawskie. Antologia. Warszawa: Muzeum Warszawy.

ZIPES, J. (1994). Fairy Tale as Myth/Myth as Fairy Tale. Kentucky: The University Press of Kentucky. 


\section{MARTA NIEWIECZERZAL}

\section{THE OLD AND NEW TOWN: THE FUTURE OF WARSAW LEGENDARY CHARACTERS}

This article presents a comparison of depictions of selected characters from traditional urban legends and their postmodern versions in contemporary Polish children's and YA literature. The analysis herein focuses on Warsaw Legends and characters related to them (the Golden Duck, Wars and Sawa, Basilisk and others). The article outlines problems associated with the future as a category concerning the individual, i.e. specific characters from the Warsaw Legends: how do they change and mature? What kind of future awaits them in the new reality? The article also examines selected narrative strategies aimed at modifying the original in the analyzed texts. 